\title{
Correction to: Intergenerational continuity of crime among children of organized crime offenders in the Netherlands
}

\author{
Meintje van Dijk ${ }^{1,2}$ (D) Veroni Eichelsheim ${ }^{2} \cdot$ Edward Kleemans $^{1}$. \\ Melvin Soudijn ${ }^{2,3} \cdot$ Steve van de Weijer ${ }^{2}$
}

Published online: 24 January 2022

(c) Springer Nature B.V. 2022

\section{Correction to: Crime, Law and Social Change https://doi.org/10.1007/s10611-021-09970-1}

The abstract was missing from this article and should have read 'As existing literature on intergenerational continuity of criminal behavior is mainly based on data on 'general' offenders and their children, the current study aims to improve our knowledge by looking at intergenerational continuity of crime among a national sample of children of organized crime offenders. Judicial data on all $(N=478)$ offenders convicted of organized crime in the Netherlands (in the period 2008-2014) and their children were used to study offspring's involvement in crime. In addition, a comparison group was selected from the entire population in the Netherlands to examine the relative risk of offending. Results show that almost half of the children of organized crime offenders have a criminal record. Sons are significantly more at risk of offending and this risk also increases strongly by age. Furthermore, the results show the strongest intergenerational relation for violent crimes. Gender of the convicted parent and timing of parental crime also seem to play a role in the continuity. With regard to the relative risk of offending, the results show that children of convicted organized crime offenders are three times more at risk of offending compared to children in the comparison group, even after controlling for the number of parental crimes. In sum, there is a substantial risk of intergenerational continuity of criminal

The original article can be found online at https://doi.org/10.1007/s10611-021-09970-1.

Meintje van Dijk

a.m.m.van.dijk@vu.nl

1 Faculty of Law, Department of Criminal Law and Criminology, Vrije Universiteit Amsterdam, Amsterdam, the Netherlands

2 Netherlands Institute for the Study of Crime and Law Enforcement (NSCR), Amsterdam, the Netherlands

3 Central Intelligence Division, Research \& Analysis, National Police of the Netherlands, The Hague, the Netherlands 
behavior among children of organized crime offenders. Future research would benefit from focusing on how criminal behavior in these specific families is transmitted to future generations.'

Also, the copyright holder was incorrectly given as 'Springer Nature B.V.' but should have been 'The Author(s)'.

The original article has been corrected.

Publisher's note Springer Nature remains neutral with regard to jurisdictional claims in published maps and institutional affiliations. 